\title{
Atmosfære på museum - at (be)gribe en stemning
}

\author{
Pernille Henriette WiIl
}

Title: Atmosphere in the museum - how to grasp a mood

\begin{abstract}
Atmospheres are strange - evasive and yet profound. Bound to space, they can affect our very being by colouring our perception and influencing our moods. In this article I will demonstrate how an awareness of the atmospheres in the house museum of the architect Marius Pedersen can provide a comprehension of the ambiguity in Bedre Byggeskik's architectural project - an ambiguity that has proven difficult to grasp otherwise. Through an exploration of the two dominant spaces (the front garden and the entrance room), I will focus on the potentials of the atmospheres as ways of recognizing the actual house as the object of the house-museum. Because of their uncertain status of being "in-between" (as inbetween subject-object, consciousness-unconsciousness, material-immaterial), the atmospheres offer a kind of evocative communication that exceeds the deliverance of "facts". The experiencing of atmospheres often evokes past experiences of similar atmospheres that affect the moods of the house museum's guests. These moods can be considered existential given that they simultaneously contain the past, the present and the possible future in a privileged space in-between reflection and emotion.
\end{abstract}

Keywords: Atmosphere, Bakkekammen 45, Bedre Byggeskik, bodily presence, ecstasies, house museums, moods, poetic representation.

And in the old house

I feel its russet warmth

Comes from the senses

to the mind

(Jean Wahl 1945)
Dette lille digt repræsenterer fænomenet atmosfære på smukkeste vis. Det fortæller os, at atmosfærer er knyttet til rum, at atmosfærer ofte karakteriseres gennem synæstesi (rødbrun varme), og at atmosfærer skal mærkes, før de kan begribes. Men ikke mindst stemmer digtet os, når vi læser det; vi føler atmosfæren i det gamle hus. 


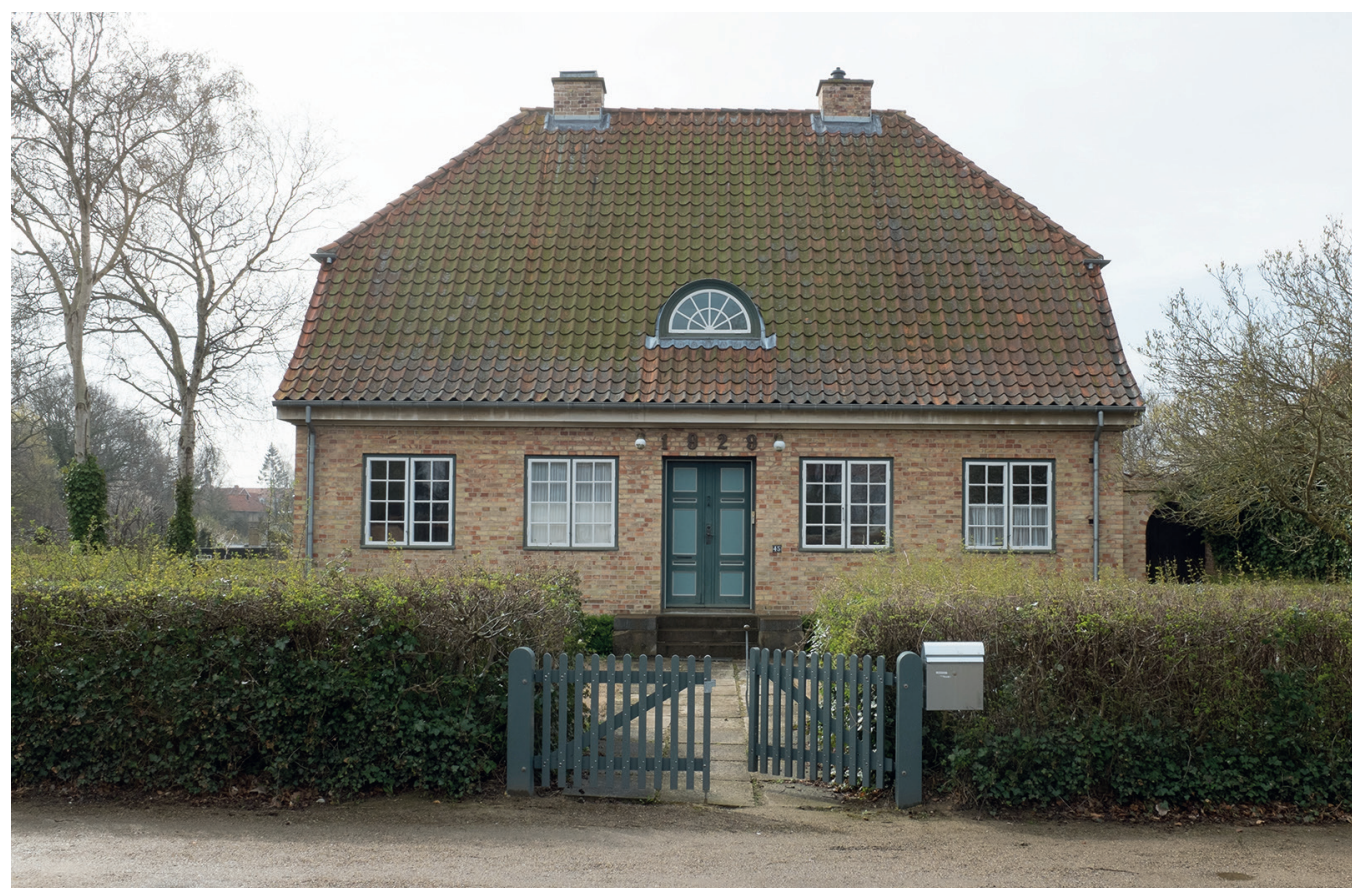

Fig. 1. Bakkekammen 45 i Holbok er tegnet af arkitekten Marius Pedersen, som også selv boede $i$ huset. Det er i dag museum for Bedre Byggeskik. Foto: Jens K. Nørgaard, 2015.

I denne artikel vil jeg argumentere for, at netop atmosfære er hjem-museernes fremmeste kvalitet. Endvidere vil jeg vise, hvordan de stemninger, som hjem-museets atmosfærer skaber hos gæsterne, kan forstås som et dannelses- og formidlingsmæssigt potentiale.

\section{HJEM-MUSEUM}

En bolig er et sted organiseret omkring en række specifikke aktiviteter og funktioner, der skal forløbe på bedst mulig måde. Der skal soves, spises, bades, hygges, haves gæster, laves lektier, vaskes tøj og gøres rent. Dertil er der indrettet soveværelser, køkkener, spisestuer, badeværelser, stuer, sofahjørner, arbejdsværel- ser og bryggerser. Men et hjem er meget mere end dets umiddelbare funktion og organisation. Det er også rumligheder, overflader, stofligheder, lugte, lyde, lys og farver - alt dette er elementer, der opleves gennem vores kropslige tilstedeværelse, og som påvirker os på afgørende måder. Ifølge fænomenologien er det at bo og befinde sig i et hjem ikke kun et spørgsmål om praktiske foranstaltninger, hvor vores kroppe kan få tilgodeset fundamentale behov, men det at bo er også et eksistentielt forehavende - det handler om vores væren-i-verden (Heidegger 2000). Dermed forstås vores krop ikke kun som et fysisk korpus, men som en eksistentiel krop der befinder sig i verden. ${ }^{2}$ Vores eksistentielle kroppe er derfor involveret i de 
42 hjem, vi skaber og bebor. Men hvad er et hjem, når det ikke længere bebos? Hvad sker der med et hjem, når det bliver til museum? Et hjem der ikke længere bebos, efterlader en form for tomrum, men det er ikke et tomt rum. På trods af de fraværende beboere fornemmer vi stadig, at noget er tilstedeværende i huset - der er atmosfære.

\section{MUSEET SOM INDTRYKS- OG ERFARINGSRUM}

Nærværende artikel sætter fokus på museet som kropsligt indtryks- og erfaringsrum. Ved hjælp af atmosfærebegrebet vil jeg først analysere, hvordan hus og menneske - selv i den korte tid et museumsbesøg varer - indgår i et fælles atmosfærisk indtryksrum. Det er min intention at illustrere, at det er huset i sig selv, der er hjem-museets genstand, og at huset selv udstikker en retning til formidling af dette. Jeg viser, hvordan en bevidst brug af indtryksrummet, via gæsternes kropslige tilstedeværelse, kan understøtte den faktuelle viden om Bedre Byggeskik, som museet i øvrigt bibringer de besøgende. Sidst, men ikke mindst, vil jeg pege på, hvordan rummenes atmosfærer kan bringe museumsgæsterne i stemninger, der kan trække eksistentielle tråde til gæsternes egne liv og erfaringer med det at bo og "være" i rum.

\section{LANDSFORENINGEN BEDRE BYGGESKIK PÅ MUSEUM}

I 2009 åbnede Holbæk Museum³ dørene til Danmarks første interiørmuseum for Landsforeningen Bedre Byggeskik. Arkitekt Marius Pedersen (1888-1965) opførte i 1929 huset til sig selv. Her boede og arbejdede han til sin død. Hans enke Emma Pedersen (1905-2007) blev boende i huset resten af sit liv, og takket være hende står huset i dag nærmest uforandret både udvendigt og indvendigt. I 2007 overtog Holbæk Museum huset efter en donation fra Nordea Fonden, og i 2009 åbnede huset som hjem-museum. Marius Pedersen var en fremtrædende skikkelse inden for Bedre Byggeskik (1915-65) blandt andet som rektor for Bygmesterskolen i Holbæk i årene 1921-40 (fig.1).

Landsforeningen Bedre Byggeskik opstod i 1915 som en reaktion på et vedvarende traditionstab i den nationale bygningskultur. Som sådan var foreningen del af et omfattende europæisk opgør med 1800-tallets historicistiske arkitektur kendetegnet ved rigt ornamenteret og dekoreret byggeri. Med industrialiseringen og internationaliseringen kom billige masseproducerede bygningselementer og materialer væltende ind over landets grænser. De nye materialer frembød tekniske og æstetiske muligheder, som ikke kunne håndteres af de lokale bygmestres traditionelt overleverede håndværkskunnen. Resultatet var i følge foreningen, at smagløshed og uorden bredte sig som en pest over det ganske land, hvor godt håndværk og gode naturlige materialer tidligere havde skabt en unik samhørighed mellem det danske landskab og den danske folkesjæl (Jensen-Klint 1911, Nielsen 1932). Bedre Byggeskiks kamp for kvaliteten i den landlige bygningskultur tog form af en fejring af fornuften udmøntet i en arkitektonisk renselsesproces. Væk skulle forloren pynt og uægte materialer; huse skulle bygges med respekt for håndværkets stedsbundne traditioner og materialer. Midlet i kampen var en meget aktiv (ud)dannelsesindsats rettet mod landbefolkningen og dens bygmestre. På Bygmesterskolen kunne eleverne lære at projektere mindre byggeopgaver, og for at sikre deres gode smag blev de undervist i formgivning, farve- og materialelære samt arkitektur- og kulturhistorie. Foreningens tilknyttede arkitekter udarbejdede en mængde detaljerede typetegninger til landbrug 
og mindre bolighuse, som skulle sikre den ønskede homogenitet i det nye byggeri. Desuden kunne bygherrer og bygmestre - for få eller ingen midler - få deres projekter korrigeret af Akademisk Architectforenings Tegnehjælp, så flest mulig nye bygninger overholdt de formmæssige idealer. ${ }^{4}$

\section{TVETYdighedeN I BEDRE BYgGeSKIK}

I mine undersøgelser af foreningens historie, ideer, argumenter og arkitektur støder jeg konstant på en dobbelthed, der synes at gennemtrænge hele Bedre Byggeskiks projekt, en brydning mellem det romantiske og det moderne. ${ }^{5}$ Som nævnt opstod foreningen som en reaktion på tabet af national identitet, tradition og håndværk i arkitekturen; men samtidig nærede visse centrale medlemmer stor sympati for det universalistiske æstetiske udtryk, som nyklassicismen tilbød. Denne stilretning gav blandt andet muligheder for at lave 'simple' æstetiske og arkitektoniske regelsæt, der kunne efterfølges af alle, både håndværkere og selvbyggere, således at de værste uskønheder kunne afværges. Det er dette skisma mellem nationalromantikkens følelsesfulde og stoflige traditionssøgen og ny-klassicismens forestilling om det rene, universelle og homogene, der er så svær at få hold på, når vi beskæftiger os med Bedre Byggeskik. I det følgende vil jeg vise, at hjem-museet på Bakkekammen 45 er eksemplarisk for foreningen, idet huset materialiserer denne grundlæggende tvetydighed i Bedre Byggeskiks univers. Som gæster får vi mulighed for at mærke tvetydigheden, således at den ikke blot fremstår som et akademisk udsagn - et hvorfor. Vi mærker ovenikøbet, hvordan to i teorien modsatrettede og uforenelige arkitektoniske retninger i virkeligheden fungerer sammen og skaber et hvordan gennem en atmosfære, der er helt sin egen.
Vi behøver ikke at gå længere end til forhaven på Bakkekammen 45, før vi bliver mødt af en særegen atmosfære.

\section{TRE MÅDER AT ERFARE EN FORHAVE PÅ}

Som gæst ved en omvisning på Bakkekammen 45 lagde jeg mærke til, at det var svært for de andre gæster at komme til tåls med husets forhave. Her er intet andet end sirligt revet jord i lige linjer vinkelret på facaden. Den revne jord er kun brudt af en lige række fliser fra havelågen til hovedøren og videre rundt om huset. Hvorfor var der ingen blomster, noget grønt, noget græs eller i det mindste en rigtig flisebelægning? Revet jord opfattes ikke som smukt, skønt eller hyggeligt, og derfor prøvede gæsterne at finde på rationelle brugsrelaterede argumenter for den revne jord, såsom at det er nemmere at rive jord end at slå græs, eller hvis det bliver gjort jævnligt, kommer der ikke ukrudt. Den revne jord er tydeligvis et meget magtfuldt udtryk, som animerede gæsterne, og som sådan er den et glimrende afsæt til formidling af viden om Bedre Byggeskik. I det følgende vil jeg identificere tre måder, hvorpå viden om Bedre Byggeskik kan erfares og formidles gennem huset på Bakkekammen, og det er som repræsentation, atmosfære og praksis.

\section{SOM REPRASENTATION}

Ved hjælp af historiske fakta og fortolkninger kan museet give gæsterne en forståelse af, hvorfor haven ser ud, som den gør. Museets omviser kan fortælle, at der var revet jord på gårdspladsen på Emma Pedersens barndomshjem, at der også er revet jord på Bedre Byggeskik-pioneren Martin Nyrops grav på Gentofte Kirkegård, eller at revet jord var almindeligt eller ligefrem "på mode", da huset blev bygget. Museet kan også lægge et fortolkningsperspektiv på forha- 
ven: Hvis man anskuer hele Bedre Byggeskiks projekt som et renselsesprojekt, hvor fremmede bygningsmaterialer og al unødig pynt skulle væk fra husenes facader, så er forhaven, som er renset for stort set alt, et resultat af denne proces. På denne måde formidles forhaven som en repræsentation af strukturel viden og fremstår som et udsagn om moralske værdier såsom flid, regelmæssighed, orden og renselse. Men for at begribe, hvordan disse moralske værdier virker, må man som gæst lade sig berøre af forhavens materialitet, man må mærke stemningen og lade sig opfylde af haverummets atmosfære.

Den tyske filosof Gernot Böhme, der har beskæftiget sig indgående med atmosfærebegrebet i sin æstetiske teori, fastslår, at en bygning eller en by ikke erfares gennem deres formelle egenskaber i sig selv. Derimod er det afgørende, hvad disse egenskaber får huset eller byen til at udstråle, eller hvordan egenskaberne er medbestemmende for indbyggernes kropslige dispositioner (Böhme 2014:51). Han fortsætter om forskellen mellem byer som repræsentation og byer som stemning og følelse:

It is of course an enormous pleasure for the learned to be able to decipher a city, when its history becomes transparent through stylistic features, heraldry, epigraphs, and the materials employed. But these abilities can no longer be assumed to pertain to the average citizen, and historical information frequently denies the guided tourist the possibility of experiencing anything of the city. But 'being old' or 'having grown over time' are qualities of the city that do not manifest themselves solely in signs; rather, they make an impression (they have Anmutungscharakter) that is sensed (Böhme 2014:51).

\section{SOM ATMOSFARE}

Böhme beskriver her, hvordan den ensidige formidling af fakta kan blokere for en reel op- levelse af byen og dens kvaliteter. Dette betyder imidlertid ikke, at museernes formidling skal tage form af en overfladisk æstetisering. ${ }^{6}$ Men ved at benytte sig af hjem-museets enestående mulighed (nemlig at gæsterne rent faktisk befinder sig i forhaven og kan opleve dens atmosfære) kan museets formidling uddybe gæsternes viden om, hvorfor forhaven fremtræder renset med en mere subtil - dog umiddelbar tilgængelig - erfaring af, hvordan forhavens renselse påvirker. På denne måde genereres en både refleksiv viden om og en kropslig erfaring af Bedre Byggeskiks arkitektoniske projekt. For at begribe forhaven eksistentielt må gæsterne være opmærksomme på, hvordan de befinder sig i haverummet. Det betyder, at der fra museets side skal gives plads, tid og opfordring til, at gæsterne kan mærke rummets nøgenhed. Hvad betyder det for deres befindende, at ruten fra havelågen til hoveddøren er skabt af en lige række betonfliser lagt $i$ et hav af revet jord, hvor blot et enkelt forkert trin vil efterlade et tydeligt spor i jorden? Hvad betyder det for deres indtryk af haven, at den er omgivet af massive meterbrede skarpt klippede hække, der dog er så lave, at man nemt kan se ud - og ind?

\section{SOM PRAKSIS}

Forhaven har funktionen at iscenesætte ankomsten til huset samt at etablere en visuel, men distanceret, kontakt til vejens offentlighed. Til at skabe og vedligeholde forhavens funktion og bruge dens rum er der knyttet visse aktiviteter og handlinger såsom at rive jorden, klippe hækken, feje fliserne osv. Gennem disse aktiviteter praktiseres forhaven, ${ }^{7}$ hvilket giver konkrete erfaringer $i$, hvordan de fysiske omgivelser konkret former brugernes handlingsmuligheder. At bevæge sig fra havelågen til hoveddøren er den eneste type af praksis, man som gæst udfører i forhaven. Som muse- 
umsgæst i et hjem-museum er det naturligvis svært at få lejlighed til at praktisere hjemmet man må ikke engang åbne skabene eller sidde $\mathrm{i}$ stolene. Derfor er det især den repræsentative viden, der danner grundlaget for forståelsen af hjemmet, hvilket selvfølgelig er grundlaget for enhver formidling. Men den kropslige erfaring knyttet til atmosfærebegrebet rummer, som vi skal se, et stort formidlingspotentiale i hjem-museerne.

\section{ET ÆSTETISK BEGREB}

I dagligdagen bruger vi ordet atmosfære om det særlige uhåndgribelige ekstra, der er ved et sted, en ting, et menneske eller en situation (Griffero 2014:6). Vi kender også atmosfære som et meteorologisk fænomen (Ingold 2011), som noget der omslutter jorden og optages i vores kroppe gennem vores åndedrag. Atmosfærer er i den forstand uundgåelige og gennemtrængende. De omslutter og indhyller os til enhver tid. Først og fremmest kan vi slå fast, at atmosfærer handler om en sanselig erfaring af verden, og dermed relaterer de til æstetik som læren om den sanselige erkendelse (Bisgaard \& Friberg 2006). I æstetisk teori beskriver atmosfærer det, der forbinder mennesket med verden. Atmosfærer er stemte rum, og som sådan tilhører atmosfærer hverken det sansende subjekt eller det sansede objekt, men behøver begge for at forekomme. Således angår atmosfære det diffuse fælles rum, hvor objektet gennem sin materielle tilstedeværelse strækker sig ud og når subjekternes befindende (Böhme 1993). Dette fælles rum er i evig tilblivelse - det er aldrig stillestående. Det vil sige, at alle tilstedeværende subjekter og objekter principielt er medskabere af atmosfæren, men ikke nødvendigvis med lige stor kraft. Atmosfærebegrebets uafklarede ontologiske status genfindes i æstetikkens erkendelsesteoretiske diskussioner om den overfladiske oplevelses potentiale i forhold til den dybe erfarings værdi (Bisgaard 2006, Kyndrup 2008:8). ${ }^{8}$ I denne diskussion har dannelsesmomentet i æstetikken som regel været knyttet til den dybe erfaring og hermed til det refleksive, men som denne artikel vil vise, kan atmosfære skabe affektive stemninger, der uden at være artikulerede kan påvirke vores befindende og tone vores møde med verden.

\section{At BEFINDE SIg}

For at forstå atmosfærebegrebet nærmere bliver vi nødt til at dykke ned i Gernot Böhmes æstetiske teori, som han uden bæven kalder en "ny æstetik" (Böhme 1993). ${ }^{9}$ Atmosfære handler om tilstedeværelse i rum; dels min egen tilstedeværelse og dels tilstedeværelsen af omgivelserne (objekter, mennesker, natur mv.). Omgivelsernes egenskaber træder frem i rummet og toner det, bøjer det og gør sig mærkbare for mit befindende. Derfor bliver begrebet "befindende" helt centralt i Böhmes teori om atmosfære. På tysk og på dansk har udtrykket sich befinden - at befinde sig - en dobbeltbetydning, som er vigtig for forståelsen af atmosfære. Som gæst på Bakkekammen kan jeg spørge, hvor jeg befinder mig, men jeg kan også spørge, hvordan jeg befinder mig - hvordan føler jeg mig tilpas? (Böhme 2013:122) Atmosfærer mærker vi i vores befindende. ${ }^{10}$

Atmosfære er - ligesom befindende - et dobbelttydigt begreb. Det dobbelttydige i atmosfære udtrykkes som modsætninger i et spændingsfelt mellem væren og ikke-væren. Atmosfærer kan - som rum - ikke ses, føles, smages, lugtes, eller berøres, til gengæld kan de tydeligt mærkes. Atmosfærer tilhører hverken den fysiske verden eller det menneske, der mærker dem. Derfor kalder Böhme atmosfærer kvasi-objektive. Han betegner dem også som kvasi-autonome, fordi atmosfærer på 


\section{Pernille Henriette WiIl}

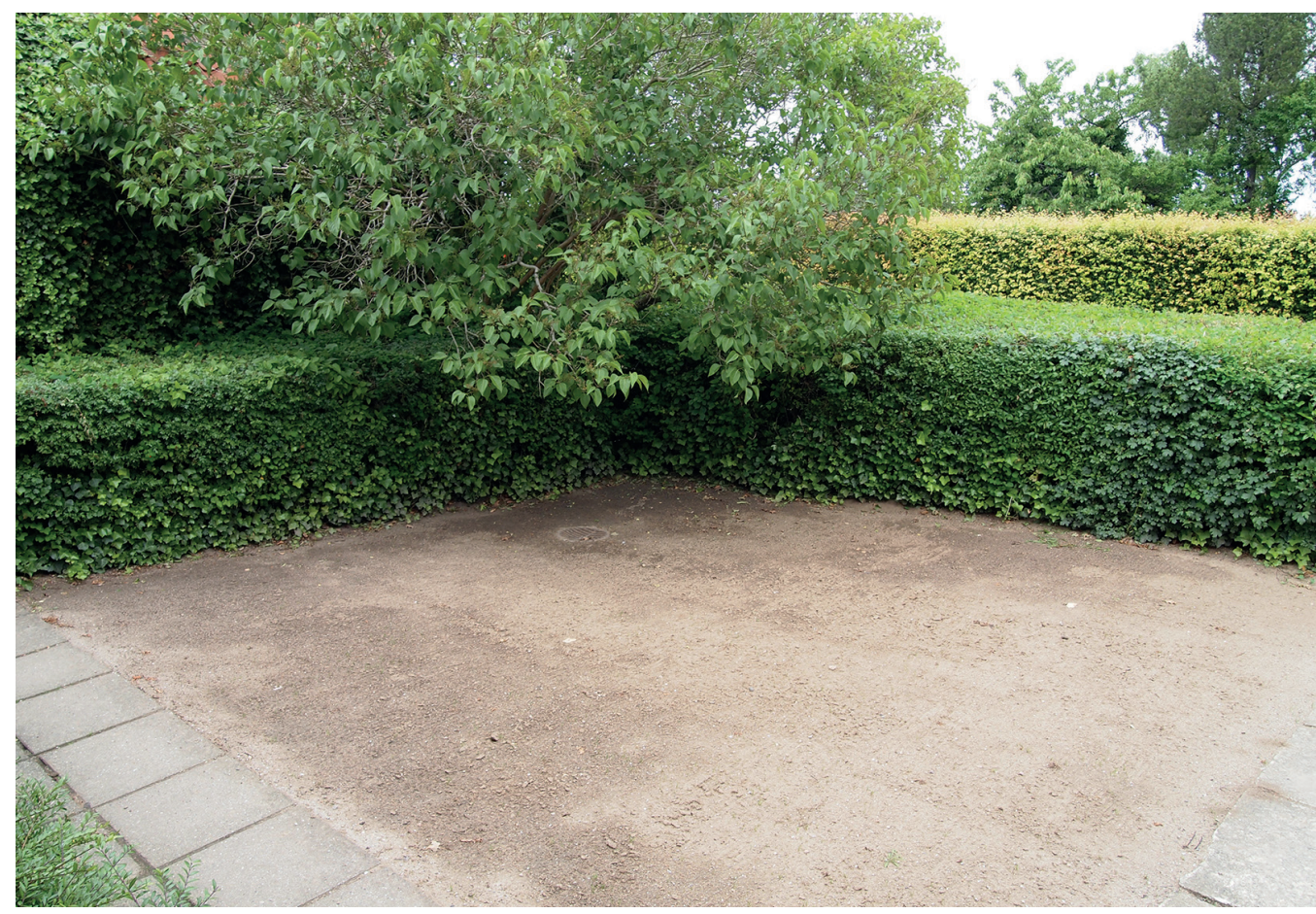

Fig. 2. Den revne jord i forhaven. Foto: Pernille Henriette Wiil, 2013.

den ene side er bundet til fænomener i verden (ting, mennesker, rum, situationer), men på den anden side er de ikke det samme som fænomenerne. Atmosfærer har deres egen karakter, da de så at sige overskrider det fænomen, de stammer fra, og strækker sig ud i rummet. Hvordan dette foregår, ser vi nærmere på i det næste afsnit.

\section{DEN REVNE JORDS EKSTASE}

I forhaven var det tydeligt, at den revne jord er et betydningsfuldt element. Men det jeg perciperede, var ikke jord, der var revet, men den atmosfæriske karakter af den revethed, som jorden "udstråler" og toner haverummet med. Den revne jord træder frem i haverummet med sin revethed, det vil sige som lige linjer i et velordnet, regelret, ens, gentaget mønster i et porøst materiale. Gennem denne revethed bliver jorden tilstedeværende i haverummet. Således bliver revetheden ikke blot noget, der tilhører jorden; revethed er noget, der stråler ud fra jorden og toner hele forhaven. Revetheden er altså ikke det, der adskiller jorden fra det omgivende, men derimod en måde hvorpå jorden går ud over sig selv i det, Böhme kalder ekstase:

...atmospheres are thus conceived not as free floating but on the contrary as something that proceeds from and is created by things, persons or their constellations. Conceived in this fashion, atmospheres are neither something objective, that is, qualities possessed 


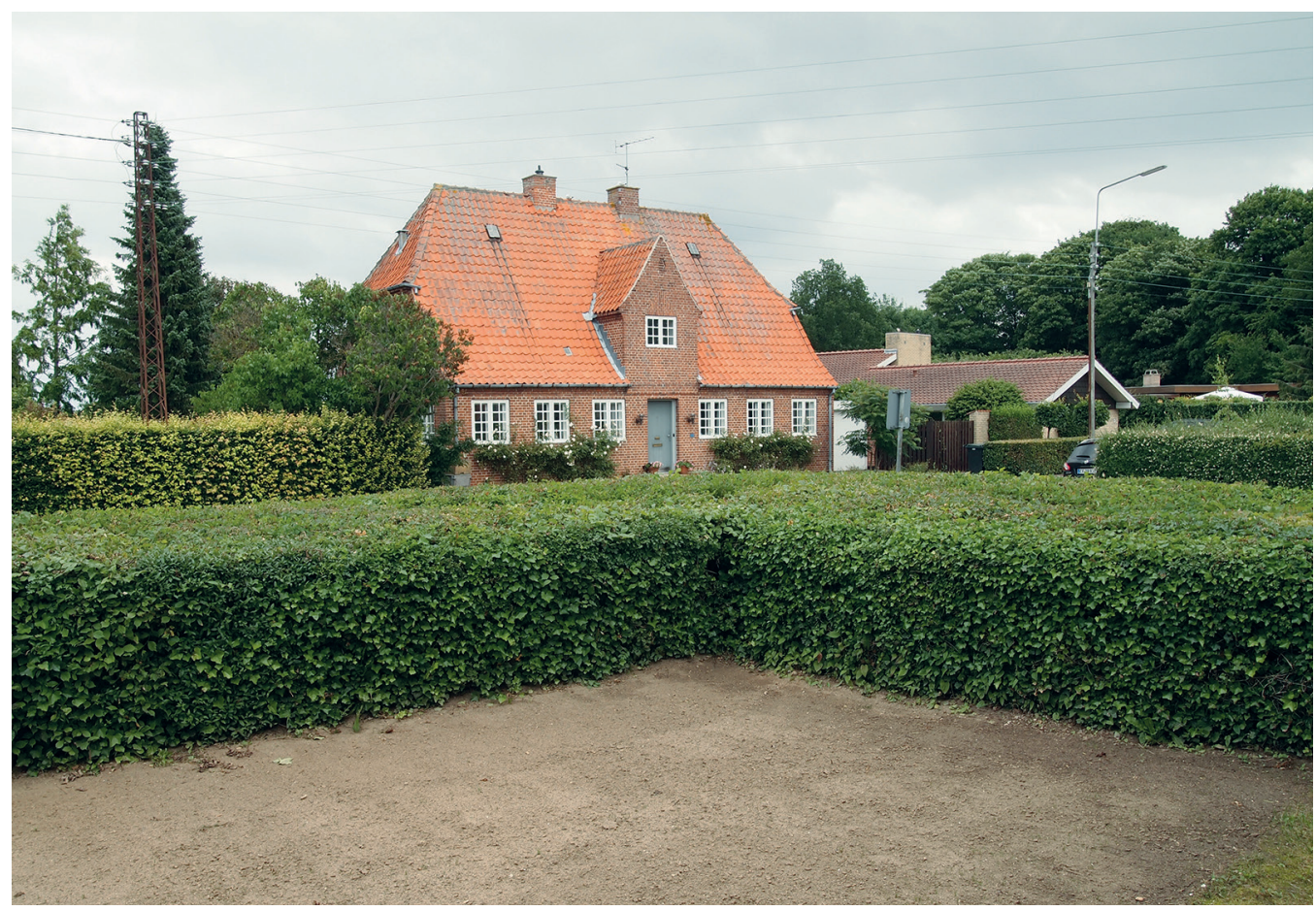

Fig. 3. Forhavens lave hoekke. Foto: Pernille Henriette Wiil, 2013.

by things, and yet they are something thinglike, belonging to the thing in that things articulate their presence through qualities-conceived as ecstasies. Nor are atmospheres something subjective, for example, determinations of a psychic state. And yet they are subjectlike, belong to subjects in that they are sensed in bodily presence by human beings and this sensing is at the same time a bodily state of being of subjects in space (Böhme 1993:122).

Ifølge Böhme skal atmosfære ikke forstås som noget, der bare flyder frit omkring i rummet, men atmosfære er noget, der udstråles fra og optages af ting, mennesker eller deres konstellationer. Det vil sige, at det ikke er tingens fysiske målbare egenskaber, jeg perciperer, men derimod den atmosfære, som kommer i stand, når tingen træder ud i rummet og viser sin tilstedeværelse og dermed bliver tilgængelig for min perception. Atmosfære er noget mellem mig og tingen, men den er ikke noget relationelt. Den er relationen selv.

Jorden tonede - gennem sin tilstedeværelse som revethed - hele forhavens rum med revethed, hvilket jeg fornemmede i mit befindende, og som jeg karakteriserede som en atmosfære af flid, pligt, orden og renselse. Ved at befinde mig i forhaven bliver jeg indhyllet i havens atmosfære. Jeg mærker, hvordan jeg bliver optaget af ikke at fejle og træde ved siden af. ${ }^{11}$ Stående der på den smalle flisegang føles det, som om den eneste rigtige måde jeg kan "være" $i$ haven på, er med en rive i hænderne. Ved at skue ud over de lave hække bliver jeg meget be- 
vidst om, hvor jeg er, og at min tilstedeværelse er eksponeret. Det er alt sammen fornemmelser, som giver mig en før-refleksiv erfaring af, hvordan Bedre Byggeskiks krav om renselse, orden og flid kan virke.

Som museumsgæst har jeg i forhaven fået mulighed for at erfare, hvordan arkitektur kan påvirke menneskers stemninger og derved potentielt forme deres adfærd. Jeg forestiller mig, hvordan atmosfæren driver ud over de tykke lave hække, hvor den måske opblandes med andre atmosfærer og absorberes i naboers og forbipasserendes befindende.

\section{UAFSLUTTEDE OG UAFGRÆNSEDE ATMOSFARER}

Som æstetisk fænomen er atmosfærer det første, der møder os, når vi kommer til et nyt sted: "For such a phenomenological theory of perception atmospheres are the first facts of perception" (Böhme 2002:23). Atmosfærer virker i det umiddelbare. Dette første indtryk af rummets atmosfære kan beskrives med en karakter, der har præg af førsteindtrykkets entydige umiddelbarhed. Først senere begynder flere af rummets singulære elementer at træde frem i menneskers befindende.

I forhaven var det tydeligt, at et enkelt element, den revne jord, var helt afgørende for atmosfæren. Men atmosfære er netop ikke så entydigt et fænomen, som nærværende beskrivelse umiddelbart lægger op til. Beskrivelsen af den revne jord er en forenklet teori-nær beskrivelse af, hvordan vi kan forstå, at ting træder frem i rummet, henvender sig til os og genererer en atmosfære, som vi kan karakterisere. Som sådan er det ikke en retfærdig repræsentation af den kompleksitet, der er indfældet i fænomenet atmosfære. Masser af - i princippet uendelig mange - elementer som for eksempel selve huset med dets materialer, rytmer, farver osv. er med til at skabe atmosfæren i forhaven; ikke mindst er de tilstedeværende mennesker også medskabere af atmosfæren. ${ }^{12}$ Alle disse talrige elementer (nogle svage, nogle stærke) danner tilsammen en atmosfære, som er i konstant tilblivelse - den bliver fortyndet og fortættet i forhold til, hvordan vores opmærksomhed arbejder sig gennem rummet. Atmosfærer er uafsluttede og uafgrænsede. På trods af denne amorfe flertydighed fastholder atmosfærerne ofte en form for vedvarende essens fra den umiddelbare og initierende karakteristik, med mindre nye elementer indtræffer og finder sted. Hermed understreges det, at atmosfærer er ontologisk uafklarede (Bille et al. 2014).

Ovenstående illustrerer det fundamentale træk ved atmosfærer, at selvom de er knyttet til rum, kan de ikke afgrænses - de er omsluttende, men de er samtidig flydende og porøse. Men på trods af atmosfærers flygtighed handler meget arkitektur og planlægning om at holde på nogle atmosfærer og lukke andre atmosfærer ude. På den måde kommer fænomener som åbninger, døre og tærskler til at betyde meget i skabelsen og oplevelsen af atmosfærer: "As we enter a space, the space enters us," siger den finske arkitekt Juhani Pallasmaa (Pallasmaa 2014:20). Dette bliver meget tydeligt, når vi bevæger os gennem forhavens lyse atmosfære af orden, nøgenhed og renselse for at gå gennem det lille mørke vindfangs to døre og videre ind $i$ husets dunkle forstue.

\section{FORSTUEN SOM OVERGANGSRUM}

Forstuen er umøbleret og perfekt proportioneret. Den er præget af en streng symmetrisk orden kombineret med stofligt rige overflader i mørke farver og fine detaljer - alt udført med håndværksmæssig akkuratesse. Men det er de mange døre (12 styk), der træder frem og toner forstuen med egenskaber, der når alle dørene 


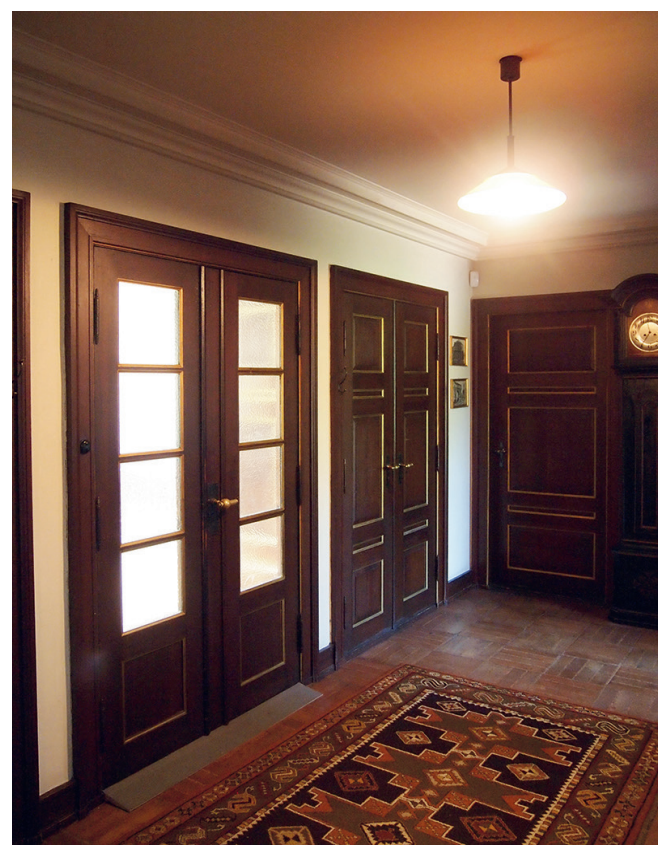

Fig. 4. Forstuens mange døre. Foto: Pernille Henriette Wiil, 2013.

er lukkede, føles som en intens og tæt atmosfære af ukrænkelighed. ${ }^{13}$ Dørene med deres profilerede indfatninger og gyldne stafferinger står vagtsomme og afventende på ræd og række med højtidelig ro. Gennem råglasset i fløjdøren til dagligstuen kommer et gyldent lys, hvori dagligstuens konturer anes som støvede skygger. Forstuen fremtræder som et tyst overgangsrum, hvor tiden står stille. Ankomsten gennem forhavens revne jord, passagen gennem vindfangets døråbninger og et kort ophold i forstuens ukrænkelige atmosfære er en overgangsrite, hvor man som gæst bliver kaldt til orden. De mange døre er materialiseringer af regler og kontrol, og de er så kraftfulde og fascinerende, fordi man som gæst bliver i tvivl, om man kan eller må åbne dem (Unwin 2007:86). Det er en kompleks atmosfære, der hersker i forstuen. Dørenes orden skaber en højtidelig og formel atmosfære, men dunkelheden og skyggerne i det gyldne lys tilføjer en fornemmelse af indelukkethed og hemmelighedsfuldhed. Atmosfæren er bogstavelig talt tung; jeg får lyst til at lukke op og lufte ud, men samtidig anspores jeg af det hemmelighedsfulde og uudgrundelige i rummet. Under mit besøg udvider forstuens døre deres rituelle betydning, idet de bliver som transitpunkter til det liv, der er blevet levet i huset, og som stadig sidder i materialiteten. Dørene er ladet med en hvisken fra tidligere liv, der udstråler fra deres overflader (Hancock 2010:115). De lukkede døre bliver tærskler til tidligere levede liv, og sammen med dunkelheden og det gyldne lys skaber de fantasier om, hvad det var, der skulle lukkes inde og hvorfor. Jeg overvejer, hvordan et liv - mit liv - kunne leves i dette hus. Momentvis dukker stemninger fra min barndom op sammen med erindringer om mystisk lukkede døre og hemmelige skabe, der med nysgerrig fryd blev åbnet og udforsket.

\section{Atmosfere-Fortetninger}

I nedenstående atmosfære-fortætning ${ }^{14}$ udvider forstuen sin eksistens fra et ankomst- og fordelingsrum til også at være et indtryksrum eller, hvad Böhme kalder et intuitivt rum (Böhme 2003:6). ${ }^{15}$ Atmosfære-fortætninger er en repræsentationsform, som jeg eksperimenterer med i min forskning om atmosfærer i Bedre Byggeskik. At bruge den poetiske genre i det videnskabelige arbejde er for mig et forsøg på at tage atmosfærebegrebets uafklarede ontologiske status alvorligt.

Atmosfærer er ikke svære at kommunikere, når man er sammen in situ i atmosfæren (Albertsen 2012). Det bliver straks sværere, når atmosfæren skal oversættes til andre rum, mennesker eller medier. Atmosfærer kan ikke flyttes, 


\author{
Døre og tærskler \\ Forstuen er gylden og dunkel \\ som et gravkammer \\ eller et skatkammer \\ 12 døre \\ bag dem gemmer sig \\ hemmeligheder og trivialiteter \\ og ting \\ Jeg forestiller mig hvilke \\ duge, koste, klude \\ frakker, hatte, paraplyer \\ breve og billeder \\ samt erindringer der hører til \\ Med spinkle stafferinger i guld \\ er dørene højtidelige og elegante \\ tærskler til et andet liv \\ en anden eksistens \\ Her er de - dørene \\ hvad det hele handler om \\ om at gå ind og ud \\ om at lukke noget af \\ lukke noget ude \\ lukke noget inde \\ om at åbne og \\ lukke det rigtige ind \\ og ikke mindst \\ om at blive \\ (Wiil 2014)
}

men vi kan etablere "billeder" af de atmosfærer, vi har sanset, og de stemninger, de har skabt. I den videnskabelige genre kommunikerer vi i det skrevne sprog. I sproget skaber vi billeder med ord, ${ }^{16}$ og nogle sproglige udtryksformer er mere billedskabende og mere stemningsgi- vende end andre. I forhold til atmosfærer gælder det om at finde en sproglig form, der kan rumme det atmosfæriske fænomens særkende, som er det diffuse, det luftige, det ubestemmelige. En form der kan kondensere atmosfærernes mange elementer til en sanselig og åben tekst, der skaber stemninger i læserens befindende. Atmosfærer repræsenterer ikke eksakte optegnelser af et givet rum, men alligevel er atmosfærer udtryk for faktiske omstændigheder i vores omverden. Derfor involverer transformationen af sansninger til ord et fænomenologisk engagement (Hancock 2010:117). Vi må vælge en sproglig repræsentation, der kan manøvrere i atmosfærernes affektive felt, men samtidig være meningsfuld. Som Hans Ulrich Gumbrecht påpeger, vil tekster der beskæftiger sig med atmosfærer og stemninger, ikke sigte mod en given sandhed, men i stedet hengive sig til den affektive og kropslige relation med omverden for på den måde at fremkalde en atmosfærisk tilstedeværelse (Gumbrecht 2012:18).

\section{TilstedeVÆrelse}

Forstuen synes at rumme noget mere end blot molekyler og atomer. Den rummer det liv, der er levet i den, og som er tilstedeværende blandt andet i de menneskelige aftryk, der er blevet sat i materialiteten. Da jeg griber om dørgrebets kølige messingkugle, mærker jeg, hvordan den er blevet blank og glat efter mange "håndtryk" - i et kort øjeblik holder jeg forstuens betydning som overgangsrum i min hånd, og jeg bliver forbundet med de mennesker, der har åbnet døren før mig. Juhani Pallasmaa udtrykker det således: "The door handle is the handshake of the building. The tactile sense connects us with time and tradition: through impressions of touch we shake the hands of countless generations [...] it is time turned into shape" (Pallasmaa 2013:62). Interaktionen mellem men- 
neske og materialitet er ikke ensidig. De menneskelige aftryk der bliver sat i materialiteten, forlener denne med en atmosfære, der får sit "eget liv" og således overskrider sin materialitet (Bjerregaard in press). ${ }^{17}$ Den arkitektoniske iscenesættelse er meget magtfuld i forstuen. Det betyder, at materialiteten er meget tilstedeværende, hvilket netop giver rum for, at noget så immaterielt som atmosfærer kan træde frem. Men på trods af deres uhåndgribelighed er atmosfærer bundet til de fysiske forekomster i verden (omgivelser, ting, mennesker osv.). I atmosfæren spores den menneskelige interaktion med materialiteten; materialiteten lejrer sig i mennesket, og mennesket lejrer sig i materialiteten, og det kan opleves på forskellige måder. Det er de menneskelige aftryk, som mange gæster forsøger at afæske materialiteten, når de besøger et hjem-museum. Materialiteten bliver et medium for kontakt til tidligere tilstedeværelse. Vi kender alle fornemmelsen af tidligere beboeres tilstedeværelse, når vi flytter ind et nyt sted. De tidligere beboeres levede liv findes som spor eller egenskaber i materialiteten - som atmosfærer, der stemmer os. ${ }^{18}$

I daglig tale kalder vi det "at indånde atmosfære", når vi undersøger atmosfæren på et nyt sted, og vi gør det ved at tage en dyb indånding og skærpe vores sanser. Det handler mere om at mærke end at forstå. Det vi ser og søger, er ofte spor af mennesker og levet liv i materialiteten, som vi håber kaster en atmosfære af sig. Filosoffen Walter Benjamin skriver om forholdet mellem spor og aura: "Sporet er tilsyneladelsen af en nærhed, hvor fjernt det end er, som efterlod det. Auraen er tilsynekomsten af noget fjernt, hvor nært det end er, som fremkalder den. I sporet får vi fat i tingen; i auraen bemægtiger den sig os" (Benjamin 2007:548). ${ }^{19}$ Når et rum eller en situation bemægtiger sig os, optages den i os, og den bliver en del af os via atmosfæren - fra den kølige stilhed i kapellet ved en begravelse til den hypnotiske rytme på et tætpakket dansegulv.

Her i forstuens rum bliver vi som gæster indhyllet i og gennemstrømmet af en atmosfære. I vores befindende skaber atmosfæren en forbindelse til husets beboere og deres fysiske tilstedeværelse gennem spor og egenskaber i materialiteten. Vores menneskelige tilstedeværelse er knyttet til det liv, der er ophobet i os, men som vi ikke har bevidst adgang til (Bencard 2014:32). Som sådan betegner tilstedeværelse en (til)væren, der går forud for den bevidste tilegnelse af omverden. I forstuen sker en kobling mellem to diffuse tilstedeværelsesformer: Min tilstedeværelse af før-bevidst ophobet liv og en immanent tilstedeværelse af de tidligere beboere etablerer et atmosfærisk rum for en samtidig eksistens, der transcenderer fortid og nutid. Dette atmosfæriske rum er et potentielt rum for dannelse, som udfoldes i de følgende afsnit om stemninger. I det atmosfæriske eller intuitive rum kan vi som museumsgæster komme på sporet af de værdier, valg og idealer, som er til stede i huset. Museumsgæsterne træder ind i en sfære af moralske dispositioner, som de ved kyndig museal vejledning kan forholde sig reflekterende til. Men det er vigtigt at understrege, at fornemmelsen af at være i rummene lagrer sig i gæsternes krop deres befindende - som en stemning, de tager med sig videre uanset refleksionsniveau.

\section{STEMNINGER}

En opmærksomhed på museets atmosfærer giver gæsterne mulighed for at få en kropslig erfaret dimension af den viden, der ellers er rettet mod det refleksive register. Derudover kan atmosfærer hensætte os i en stemthed, der bevæger os emotionelt (Anderson 2009). Da stemninger ikke er refleksivt betingede, kan vi i stemningerne rumme de endnu uaf- 
52 klarede fornemmelser, erindringer og længsler, der præger vores egen livssituation. Filosoffen Gaston Bachelard beskriver i sin klassiske bog om husets fænomenologi The Poetics of Space (1994), hvordan vores barndoms hjem er indskrevet i vores kroppe, og at alle andre huse vil opleves som variationer over temaerne i det oprindelige hus (Bachelard 1994:15). Under omvisningerne på Bakkekammen er det tydeligt, at mange museumsgæster genkalder tidligere erfaringer om at bebo. De fortæller erindringer om, hvordan de boede som børn på landet, og de reflekterer over, hvordan de bor nu og muligvis, hvordan de ønsker at bo. Ligesom jeg oplever gæsterne momenter af identifikation, der påvirker deres befindende og stemmer dem. Når det netop er tilstedeværelsen af det liv, der er levet i huset, vi vil mærke i et hjem-museum, så gør vi det gerne gennem en form for identifikation, som sker gennem vores kropslige tilstedeværelse.

I forbindelse med det akademiske arbejde med atmosfærer bliver vi som forskere ofte nødt til at bruge os selv som katalysatorer for de før-sproglige momenter i atmosfæren. Som menneske "gik jeg ind i" atmosfæren bevidst om mit eget befindende; men det betyder ikke, at det kun var mig, der blev påvirket af atmosfæren. Jeg mærkede noget, der udstrålede fra forhaven og forstuens materialitet. Böhme beskriver atmosfære som noget subjektivt, der kan deles med andre, og som vi kan få en fælles forståelse af (Böhme 2014:50). Under forudsætning af, at vi er tilstrækkeligt sociokulturelt kompatible, vil atmosfærer i stor udstrækning blive identificeret og karakteriseret på samme måde.

Atmosfærer hører til i et for mennesket vigtigt område sammen med stemninger, følelser og affekter, men atmosfærer besidder en særstilling, idet de tilhører rummet og ikke mennesket. En atmosfære er ikke blot en projektion af en subjektiv sindsstemning. En atmosfære kan bemægtige sig et menneske, der føler sig berørt. Et menneske kan møde en atmosfære, der er helt anderledes end deres egen sindsstemning. Flere mennesker kan deles om en atmosfære og en stemning. Alle de her nævnte faktorer anslår, at atmosfærer og stemninger er delikat indvævet mellem det subjektive og det objektive samt det subjektive og det inter-subjektive (Throop 2014:70).

\section{STEMNINGER SOM \\ DANNELSESPOTENTIALE}

Den kropslige fornemmelse af atmosfære er knyttet til en emotionel påvirkning af vores befindende, som vi kalder en stemning. Stemning bruges ofte som synonym med atmosfære, men det er vigtigt at holde fast $i$, at der er forskel mellem de to begreber. Forskellen består i, at atmosfærer manifesterer sig rumligt og altid er knyttet til det rum, hvori vi befinder os. Stemninger er derimod ikke stedsbundne. Stemninger er noget, vi kan bære med os ud af atmosfæren, og er således ikke afhængige af, hvor vi befinder os. Ifølge antropologen C. Jason Throop er stemninger ligesom atmosfærer ubestemmelige og uafklarede, men samtidig gennemtrængende. Stemninger har den kvalitet, at de hverken tilhører den bevidste refleksion eller den ubevidste umiddelbare sansning. Stemninger kan indeholde en vag og diffus, men vedvarende disposition rettet mod verden som Throop kalder moral moods - moralske stemninger (Throop 2014).

Forstuens atmosfære af orden, ukrænkelighed og hemmelighedsfuldhed og forhavens atmosfære af flid, orden, regelrethed og renselse, kan beskrives som atmosfærer af moralske værdier. Throop angiver, at stemninger kan rumme moralske forhold, der er i forandring og bevægelse. Fordi stemninger er uafsluttede 
og ubestemte, er det muligt for dem at rumme forskellige uafgjorte og ambivalente moralske og eksistentielle forhold og indtryk i vores liv. Alligevel kan stemninger være vedvarende; de kan forbinde uafklarede reminiscenser fra fortiden med situationer i nutiden og ønsker for fremtiden. Stemninger farver det indre rum, hvori vi træffer moralske og eksistentielle valg i vores liv. På denne måde kan vi anskue de moralske stemninger som potentialer for dannelse.

\section{ATMOSFERISK KOMPETENCE}

Tvetydighed løber som nævnt som en grundstemning igennem hele Bedre Byggeskiks arkitektoniske projekt, men betydningen af det tvetydige kan være svær at identificere, forstå og ikke mindst formidle. I denne artikel har jeg vist, hvordan atmosfærer af pligt, omhyggelighed og renselse, men også af hemmelighedsfuldhed, dunkelhed og indelukkethed kropsliggør en eksistentiel tvetydighed i arkitekt Marius Pedersens hus. Således er huset eksemplarisk som museum for Landsforeningen Bedre Byggeskik.

Vi er i atmosfærer overalt og hele tiden, og selvom atmosfærer er meget virkningsfulde, idet de påvirker både vores krop og sind, går de fleste atmosfærer, vi møder i hverdagen, tilsyneladende upåagtet hen. Atmosfærer er dagligdagsfænomener, men alligevel er atmosfærer det særlige, som et hjem-museum kan tilbyde gæsterne. Ved en bevidst iscenesættelse af besøgene kan museets personale guide gæsterne til en erfaring af atmosfærerne i og omkring huset; og det er der god grund til at gøre. Indtrykkene fra atmosfærerne kan forstærke, underbygge og supplere den formidling, som museet tilbyder gæsternes kognitive register. At erfare en atmosfære er at mærke, hvor og hvordan man befinder sig i verden. Det er en kompetence, og som sådan kan den trænes og fintunes. Museets fagfolk kan kærligt skubbe til gæsternes atmosfæriske beredskab. De kan på en ny-fortolkende måde følge i sporene på Bedre Byggeskiks æstetiske dannelsesprojekt med det selvsamme og for museet erklærede formål: at øge befolkningens evne til at påskønne, tage vare på og udvikle kvaliteterne og atmosfærerne i den danske bygningskultur. ${ }^{20}$

\section{Noter}

1. Digtet er oprindelig fra Jean Wahls bog Poèmes (1945). Oversat fra fransk til engelsk i Gaston Bachelards bog The Poetics of Space (1994:48).

2. Distinktionen mellem kroppen som Körper (fysisk krop, som objekt) og Leib (følt eller levet krop) er grundlæggende for fænomenologien, som den introduceres hos Edmund Husserl.

3. Holbæk Museum fusionerede i 2013 med fem andre kulturhistoriske museer til det nuværende Museum Vestsjælland.

4. For yderligere viden om Landsforeningen Bedre Byggeskik, Marius Pedersen og huset på Bakkekammen 45 se venligst hjemmesiden http://www. bakkekammen $45 . \mathrm{dk}$.

5. I tidsrummet 2013-16 arbejder jeg med en ph.d.-afhandling omhandlende Landsforeningen Bedre Byggeskiks arkitektoniske og ideologiske projekt i et samarbejde mellem Museum Vestsjælland og Roskilde Universitet.

6. I den omfattende æstetisering af samfundet ligger museerne i spændingsfeltet mellem inddragelsen i en begivenhedskultur og fastholdelsen af en dannelsesposition (Larsen 2006:89).

7. Det er disse oplevelser af at praktisere - enact som mange open air museer udnytter med stor succes som for eksempel det sydsvenske vikingemuseum Foteviken og det danske Trelleborg.

8. Siden Baumgarten i 1700-tallet grundlagde æstetikken som filosofisk disciplin i et forsøg på at opruste den sanselige erkendelse i forhold til den 
rationelle, har den filosofiske æstetik favoriseret den dybe æstetiske erfaring på bekostning af den mere "overfladiske" oplevelse, der opererer affektivt snarere end refleksivt. For en diskussion af distinktionen mellem overflade- og dybdeæstetik se Det cestetiskes aktualitet (Bisgaard \& Friberg 2006).

9. I sin æstetiske teori gør Böhme op med den privilegerede kunstværdsættelse og domsfældelse, som har præget den moderne filosofiske æstetik siden Kant (Böhme 1993). Böhme vender tilbage til Baumgarten, der benyttede det græske ord aistheta (sanseindtryk) som betegnelse for hans teori om sanselig erfaring.

10. På tysk kalder Böhme det Befindlichkeit. Befindlichkeit er en "sans" som er rettet mod "væren-i" og henfører dermed atmosfære-tænkningen til Martin Heideggers fænomenologiske begreb om "tilværen", Dasein (Böhme 2013).

11. Vi besøgende stod alle på den lige række af fliser. Kun et enkelt fodspor var afsat i den revne jord, da vi forlod forhaven.

12. I denne sammenhæng er det imidlertid alene et spørgsmål om at identificere dominerende arkitektoniske og materielle elementer i rummet.

13. Hvilket det skal give gæsterne tid og lejlighed til at opleve.

14. Betegnelsen "fortætning" stammer fra Jo Krøjers arbejde med poetisk repræsentation (Krøjer 2003, Krøjer \& Hølge-Hazelton 2010).

15. Anschauungsraum kalder Böhme det på tysk.

16. Her refererer jeg ikke kun til brugen af metaforer, men til alle sprogets muligheder for at skabe indtryk.

17. Bjerregaard taler om, at museets objekter opløses og giver plads for et atmosfærisk "mellemværende" mellem museets genstande og museets besøgende (Bjerregaard in press).

18. Tilstedeværelsen af tidligere beboeres liv føles ofte meget påtrængende, og det er noget vi ofte gør meget for at fjerne, for eksempel ved at gøre hovedrent og male vægge - også selvom det måske ikke er "nødvendigt".
19. Böhmes atmosfærebegreb er udviklet med et blik på Benjamins aurabegreb, som Benjamin definerer som en særlig egenskab ved (det originale) kunstværk, som han udfolder det i essayet Kunstverket $i$ dets tekniske reproducerbare tidsalder (1994) (på tysk 1939).

20. En stor tak til seniorforsker på Museum Vestsjælland Minna Kragelund for kommentarer og tålmodige gennemlæsninger af tidligere udgaver af denne artikel.'

\section{LITTERATUR}

Albertsen, Niels 2012. "Gesturing atmospheres." I Jean-Paul Thibaud \& Daniel Siret (red.). Ambiances in Action. Proceedings of the 2nd International Congress of Ambience. Danadien Centre for Architecture, Montreal, September 2012. Mayenne: International Ambience Network, 69-74. https://halshs.archives-ouvertes. fr/halshs-00745 (downloadet 27. februar 2014)

Anderson, Ben 2009. "Affective atmospheres." Emotion, Space and Society 2, 77-81.

Bachelard, Gaston 1994. The Poetics of Space. Boston: Beacon Press.

Bencard, Adam 2014. "Presence in the museum. On metonymies, discontinuity and history without stories." Museum and Society 12:1, 29-43.

Benjamin, Walter 1994. "Kunstværket i dets tekniske reproducerbare tidsalder". KઐK 77:1, 15-42.

Benjamin, Walter 2007. Passageveerket. Bind 1. København: Forlaget Politisk Revy.

Bisgaard, Ulrik 2006. "Æstetikkens overflade og dybde - shoppingcenteret i et nyt lys." I Ulrik Bisgaard \& Carsten Friberg (red.). Det aestetiskes aktualitet. København: Multivers, 100-112.

Bjerregaard, Peter, in press. ”Dissolving objects. Museums, atmosphere and the creation of presence." Emotion, Space and Society http://dx.doi.org/10.1016/j.emospa.2014.05.002 (downloadet 20. september 2014)

Böhme, Gernot 1993. "Atmosphere as the fundamental 
concept of a new aesthetics." Thesis Eleven 36, 113-126.

Böhme, Gernot 2002. "Synesthesia in a phenomenology of perception." Cloud-CuckooLand, International Journal of Architectural Theory18:31, 21-33. Gentrykt fra Hans Adler \& Ulrikke Zeuch (red.) 2002. Synästhesie: Interferenz, Transfer, Synthese der Sinne. Würzburg: Königshausen \& Neumann http://cloud-cuckoo.net/fileadmin/issues_en/ issue_31/article_boehme.pdf [25.11.2013] (downloadet 22. august 2014)

Böhme, Gernot 2003. "The space of bodily presence and space as a medium of representation." I Mikael Hård, Andreas Lösch \& Dirk Verdicchio (red.) 2003. Transforming Spaces. The Topological Turn in Technology Studies. International Conference Darmstadt, Germany http:// www.ifs.tu-darmstadt.de/fileadmin/gradkoll// Publikationen/transformingspaces.html (downloadet 21. juni 2014)

Böhme, Gernot 2013. Architektur und Atmosphäre. München: Wilhelm Fink Verlag.

Böhme, Gernot 2014. "Urban atmospheres. Charting new directions for architecture and urban planning." I Christian Borch (red.). Architectural Atmospheres. On the Experience and Politics of Architecture. Basel: Birkhäuser, 42-59.

Griffero, Tonino 2014. Atmospheres. Aesthetics of Emotional Spaces. Surrey: Ashgate.

Gumbrecht, Hans Ulrich 2012. Atmosphere, Mood, Stimmung. On a Hidden Potential of Literature. Stanford: Stanford University Press.

Hancock, Nuala 2010. "Virginia Woolf's glasses. Material encounters in the literary/artistic house museum." I Sandra H. Dudley (red.). Museum Materialities. Objects, Engagements, Interpretations. London: Routledge, 114-127.

Heidegger, Martin 2000. Sproget og ordet. København: Hans Reitzel.

Ingold, Tim 2011. Being Alive. Essays on Movement, Knowledge and Description. London: Routlege.
Jensen-Klint, Peder Vilhelm 1911. Bygmesterskolen.

København: Gyldendalske Boghandel Nordisk Forlag.

Krøjer, Jo 2003. Det morkede sted - køn, krop og arbejdsrelationer. Ph.d.-afhandling fra Forskerskolen i Livslang Læring. Roskilde: Roskilde Universitetsforlag.

Krøjer, Jo \& Bibi Hølge-Hazelton 2010. "Poethical. Breaking ground for reconstruction." International Journal of Qualitative Studies in Education 21:1, 27-33.

Kyndrup, Morten 2008. Den oestetiske relation. Sanseoplevelsen mellem kunst, videnskab og filosofi. København: Gyldendal.

Larsen, Louise C. 2006. "Det performative museum." I Ulrik Bisgaard \& Carsten Friberg (red.). Det oestetiskes aktualitet. København: Multivers.

Nielsen, Harald 1932. Bygmesterbogen. København: Nyt Nordisk Forlag Arnold Busk.

Pallasmaa, Juhani 2013. The Eyes of the Skin. Architecture and the Senses. Chichester: Wiley.

Pallasmaa, Juhani 2014. "Space, place, and atmosphere. Peripheral perception in existential experience." I Christian Borch (red.). Architectural Atmospheres. On the Experience and Politics of Architecture. Basel: Birkhäuser, 18-41.

Throop, C. Jason 2014. "Moral Moods." Ethos 42:1, 65-83 (downloadet 5. juni 2014)

Unwin, Simon 2007. Doorway. Abingdon: Routledge.

Pernille Henriette Wiil, arkitekt, cand. poed. $i$ didaktik, ph.d.-studerende $i$ et samarbejde mellem Museum Vestsjolland og Roskilde Universitet

Wiil@ruc.dk

Roskilde Universitet

Institut for miljø, samfund og rumlig forandring (ENSPAC)

Universitetsvej 1, Bygning 02

DK-4000 Roskilde, Danmark 